\title{
Control of Russet Crack Disease in Sweetpotato Plants Using a Protective Mild Strain of Sweet potato feathery mottle virus
}

\author{
Shuichi Yamasaki, Oita Prefectural Agriculture, Forestry and Fisheries Research Center, Oita 872-0103, Japan; \\ Junichi Sakai, National Agricultural Research Center for Tohoku Region, Iwate 020-0198, Japan; Shigeru \\ Kamisoyama and Hideyo Goto, Oita Prefectural Agriculture, Forestry and Fisheries Research Center, Oita 872- \\ 0103, Japan; Mitsuru Okuda, National Agricultural Research Center for Kyushu Okinawa Region, Kumamoto 861- \\ 1192, Japan; and Kaoru Hanada, National Agricultural Research Center, Ibaraki 305-8666, Japan
}

\begin{abstract}
Yamasaki, S., Sakai, J., Kamisoyama, S., Goto, H., Okuda, M., and Hanada, K. 2009. Control of russet crack disease in sweetpotato plants using a protective mild strain of Sweet potato feathery mottle virus. Plant Dis. 93:190-194.

A mild isolate (designated as 10-O) of Sweet potato feathery mottle virus (SPFMV) was obtained from Ipomoea batatas. This isolate rarely caused skin discoloration and did not cause russet crack disease on the storage roots of I. batatas that are typical of infection with the severe strain of SPFMV (SPFMV-S). The yield of the 10-O-infected I. batatas ranged from 92 to $105 \%$ of the yield of healthy I. batatas. The coat protein gene of $10-\mathrm{O}$ encodes 315 amino acids and has sequence identities of $91.1 \%$ at the nucleotide level and $95.6 \%$ at the amino acid level with the corresponding region of SPFMV-S. When I. batatas cuttings were inoculated with 10-O and later challenged with SPFMV-S, russet crack symptoms were much reduced and SPFMV-S was not detected in the challenged plants. These results indicate that $10-\mathrm{O}$ can be an effective biological control agent against russet crack disease.
\end{abstract}

Additional keywords: cross-protection

Sweetpotato (Ipomoea batatas L.) is a major field crop in Japan. In 2005, approximately 1 million tons of sweetpotato were harvested, ranking Japan sixth in the world in sweetpotato production (Food and Agriculture Organization corporate statistical database [FAOSTAT] Classic). In the southern part of Japan, some varieties of sweetpotato are commonly cultivated for use in the manufacture of distilled spirits.

Some strains of Sweet potato feathery mottle virus (SPFMV), a member of the genus Potyvirus (25), cause russet crack and skin discoloration of the storage roots of I. batatas. Several strains of SPFMV have been distinguished on the basis of symptom differences, amino acid sequence identities, and serological relationships $(1,2)$. In Japan, three strains have been described, SPFMV-O (26), SPFMV-T (24), and SPFMV-S (25). SPFMV-S causes russet crack and severe skin discoloration on the storage roots. Although SPFMV-O is serologically related to SPFMV-S, it induces only mild skin discoloration (26).

Corresponding author: Shuichi Yamasaki E-mail: yamasaki-shuichi@pref.oita.lg.jp

* The $e$-Xtra logo stands for "electronic extra" and indicates that Figure 1 appears in color online.

Accepted for publication 30 September 2008.

doi:10.1094/PDIS-93-2-0190

(C) 2009 The American Phytopathological Society
SPFMV-T is asymptomatic on the roots and is serologically related to SPFMV-S and SPFMV-O by complement fixation test, but is not detected by SSEM using protein A gold and protein A sandwich enzyme-linked immunosorbent assay (ELISA) using antisera made against SPFMV-S or SPFMV-O (24). SPFMV-S and SPFMV-O are transmitted by the green peach aphid (Myzus persicae) $(25,26)$, although the primary vector of SPFMV-T in the field is unknown.

In Oita Prefecture, Japan, SPFMV is estimated to infect 10 to $40 \%$ of the sweetpotato crop in any given year, resulting in a 20 to $50 \%$ reduction in yield and quality (13). To maintain the best quality of skin color, sweetpotato is often planted using virus-free cuttings, and then cuttings from those plants are used to plant the subsequent years' crops. Usually the incidence and disease severity of SPFMV-S is low in the first crop due to limited transmission of the virus by aphids; however, cuttings from these plants often produce roots with typical symptoms of russet crack and severe skin discoloration. Not all farmers purchase virus-free cuttings each year due to the expense, so virus incidence continues to increase in subsequent years' crops. Other strategies for virus disease control are lacking for sweetpotato.

Cross-protection is a phenomenon in which systemic infection of a plant with one strain of a virus, generally an attenuated or less virulent strain, prohibits or restricts secondary infection by a related, more virulent viral strain $(6,12,17)$. Crossprotection has been used as a management strategy for several viruses, including $\mathrm{Pa}$ paya ringspot virus (7), Citrus tristeza virus (4), Cucumber mosaic virus (22), Zucchini yellow mosaic virus $(9,10)$, Japanese yam mosaic virus (5), and Bean yellow mosaic virus (23) in many different crops, including those propagated by vegetative reproduction (7). The idea that culling out roots with russet crack symptoms has resulted in selection of strains of SPFMV that confer cross-protection was suggested by Campbell et al. (3); however, mild isolates of SPFMV that can protect $I$. batatas from severe disease have not been characterized.

In this study, an isolate of SPFMV from I. batatas roots that induced mild or undetectable disease was identified and characterized, and shown to be effective at protecting plants from subsequent infection with a virulent isolate.

\section{MATERIALS AND METHODS}

Growing conditions for plants. SPFMV is very difficult to transmit mechanically to I. batatas, and graft-inoculation is the most effective means of transmission. On the other hand, I. nil at the cotyledonary stage can be readily infected with SPFMV by mechanical transmission, and these I. nil seedlings were then used to graft-inoculate large numbers of $I$. batatas plants that could be planted in the field. To challenge the $I$. batatas plants infected with mild isolate(s), SPFMV-S-infected $I$. nil seedlings were grafted onto the sweetpotato plants.

To mechanically inoculate $I$. nil seedlings, sap from symptomatic leaves of $I$. nil plants previously infected with SPFMV was triturated in 100 volumes of $0.1 \mathrm{M}$ potassium phosphate buffer (pH 7.0) rubbed onto the cotyledons of healthy $I$. nil seedlings. These seedlings were grown for 2 weeks, by which time they developed typical symptoms on upper leaves, and then grafted onto I. batatas ('Tosabeni') cuttings at the three-open-leaf stage. These were grown in a growth chamber at $25^{\circ} \mathrm{C}$ in $16 \mathrm{~h}$ of daylight for 2 weeks, the SPFMV-infected I. nil scion was removed from the I. batatas cuttings, and these cuttings were planted in the field. Daugh- 
ter storage roots produced on these plants were used for further experiments.

Screening for mild isolates. Approximately 50,000 storage roots of I. batatas were harvested over 5 years from four fields in Oita Prefecture, Japan. A total of 249 storage roots showing mild skin discoloration were selected to search for mild isolates of SPFMV. SPFMV infection of the roots was first confirmed by reverse transcription-polymerase chain reaction (RT-PCR). Total RNA was extracted using Isogen (Nippon Gene, Japan) according to the manufacture's protocol. RT-PCR was performed using a GeneAmp RNA PCR kit (Applied Biosystems, Foster city, CA) under the following conditions: (i) RT, 20 min at $42^{\circ} \mathrm{C}$ and 6 min at $99^{\circ} \mathrm{C}$; (ii) PCR, 40 cycles of $95^{\circ} \mathrm{C}$ for $40 \mathrm{~s}, 53^{\circ} \mathrm{C}$ for 1.5 min, and extension at $72^{\circ} \mathrm{C}$ for $2 \mathrm{~min}$, final extension at $72^{\circ} \mathrm{C}$ for $10 \mathrm{~min}$. Nucleotide primers 5'-CACTTCAGTGACGTTGCT GA-3' and 5'-GGCTCGATCACGAAC CAAAA- $3^{\prime}$ were designed from the coat protein $(\mathrm{CP})$ gene and the $3^{\prime}$ untranslated region, respectively, of SPFMV-S and -O, and amplify a 545-bp DNA fragment (1416). RT-PCR products were fractionated on a $2 \%$ agarose gel and visualized under UV light after staining with ethidium bromide $(50 \mu \mathrm{g} / \mathrm{ml})$.

Storage roots with mild symptoms and confirmed to be infected with SPFMV were planted in a greenhouse, and cuttings were taken from the shoots when they reached the three-open-leaf stage. These cuttings were subsequently challenged with SPFMV-S and grown in the field. These experiments were conducted each year from 1995 to 1999 , and daughter storage roots produced on these challenged plants that continued to show mild symptoms were used for further experiments.

Separation and selection of mild isolates. To obtain pure isolates of mild SPFMV, the I. batatas daughter storage roots were planted in a greenhouse, and infected cuttings at the three-fully-openleaf stage were transplanted and grown in the greenhouse. Healthy $I$. nil seedlings at the cotyledonary stage were grafted onto the infected plants, and upper leaves from these scions were selected when symptoms developed and used to mechanically inoculate Chenopodium amaranticolor and $C$. quinoa plants in an attempt to obtain local lesion isolates.

RT-PCR and restriction fragment length polymorphism (RFLP) analyses. Two assays were used to discriminate between SPFMV isolates. The nucleotide primers 5'-GACAACACACTTATGGTT GT-3' and 5'-CGCGCAAGACTCATATCA GT-3' were designed from the NIb and the CP cistrons, respectively, of SPFMV-S and SPFMV-O $(8,14,15)$. They amplify a 1,343-bp DNA fragment. RT was carried out by incubation at $42^{\circ} \mathrm{C}$ for $20 \mathrm{~min}$, followed by incubation at $99^{\circ} \mathrm{C}$ for $6 \mathrm{~min}$. PCR of the cDNA was carried out by incu- bation of 30 cycles of $40 \mathrm{~s}$ at $95^{\circ} \mathrm{C}, 1.5 \mathrm{~min}$ at $53^{\circ} \mathrm{C}$, and $2 \mathrm{~min}$ at $72^{\circ} \mathrm{C}$, with a final extension for $7 \mathrm{~min}$ at $72^{\circ} \mathrm{C}$. The amplified products of each isolate were digested with restriction enzymes EcoRI and BamHI following the manufactures protocol and fractionated on $2 \%$ agarose gel.

A second assay used three oligonucleotide primers: 490-RT (5'-GATTTAGGT GACACTTAGTTTTTTTTTTTTTTTTTG$\left.3^{\prime}\right), \quad 490-5^{\prime} \quad$ (5'-ATGAGTCTTGCGCGA TATGC-3'), and 490-3' (5'-GATTTAGGT GACACTATAG- $3^{\prime}$ ) designed from the CP gene and the $3^{\prime}$ untranslated region $(14,18,19)$. RT was carried out with primer 490 -RT by incubation at $42^{\circ} \mathrm{C}$ for $20 \mathrm{~min}$, followed by incubation at $99^{\circ} \mathrm{C}$ for $6 \mathrm{~min}$. PCR of the cDNA was carried out with the two primers, 490-5' and 490-3', by incubation at $95^{\circ} \mathrm{C}$ for $1 \mathrm{~min}$, followed by 35 cycles of $15 \mathrm{~s}$ at $94^{\circ} \mathrm{C}, 30 \mathrm{~s}$ at $45^{\circ} \mathrm{C}$, and 1 min at $72^{\circ} \mathrm{C}$, with a final extension for 7 $\min$ at $72^{\circ} \mathrm{C}$. The amplified products from each isolate were digested with restriction enzyme $A l u \mathrm{I}$ and fractionated on $2 \%$ agarose gel.

Partial nucleotide sequence of a mild isolate selected. The $3^{\prime}$-terminal $1781 \mathrm{nt}$ encoding bp fragment containing the $\mathrm{NIb}$ gene, the CP gene, and the $3^{\prime}$ untranslated region of a mild isolate referred to as $10-\mathrm{O}$ (selected because this isolate produced milder symptoms on upper leaves of $I$. nil than the other isolates and showed good protection on sweetpotatoes against SPFMV-S; see results for detail) was amplified by RT-PCR as described by Mori et al. (15). The amplified fragment was cloned into the plasmid vector $\mathrm{pBluescript}$ SKII+ (Stratagene, Torrey Pines Road, La Jolla, CA) and sequenced by the dideoxynucleotide chain termination method by using ABI373A (Applied Biosystems, Foster City, CA).

Host range and pathogenicity of the 10-O SPFMV isolate. The mild isolate 10$\mathrm{O}$ was mechanically inoculated to I. batatas (cv. Tosabeni, Koukei-14, Tamaotome, and Beniazuma), I. nil, I. setosa, Chenopodium amaranticolor, C. quinoa, Nicotiana benthamiana, N. glutinosa, N. tabacum 'Xanthi-nc', Vigna sesquipedalis, Solanum lycopersicum, $S$. melongena, Capsicum annuum, Petunia hybrida, Cucumis sativus, C. melo, Raphanus sativus, and Brassica oleracea var. capitata. I. batatas was also graft-inoculated by $10-\mathrm{O}-$ infected $I$. nil seedlings. Three separate plants were inoculated for each species. Inoculated leaves and upper leaves from the inoculated plants were sampled when they showed apparent symptoms, and the virus infection was examined by RT-PCR. Those that did not show any symptoms were similarly examined 21 days after inoculation.

Cross-protection tests of 10-O against SPFMV-S. I. batatas plants were infected with SPFMV 10-O using graft-inoculation as described above. Infection with 10-O was confirmed by RT-PCR followed by $A l u \mathrm{I}$ digestion, and the cuttings were multiplied in a greenhouse equipped with 1$\mathrm{mm}$ mesh netting in order to protect them from subsequent aphid-borne virus infection. The 10-O-infected I. batatas ('Tosabeni') were challenge-inoculated with SPFMV-S using graft-inoculation as described above and grown each year from 2000 to 2003 in the field. 10-O-infected and virus-free $I$. batatas cuttings were used as controls. After harvest, storage roots were evaluated for symptoms, number, and fresh weight. Symptom severity for each storage root was scored by the formula described in Table 1. Every year, leaves were sampled from 10 SPFMV-Sinoculated cuttings and 10-O-infected cuttings at approximately 30 days after transplanting, and infection by SPFMV-S was determined by RT-PCR followed by AluI digestion.

Transmission by aphids. Myzus persicae reared on I. batatas ('Tosabeni') in a growth chamber were starved for $2 \mathrm{~h}$ and placed on 10-O-infected I. nil for $10 \mathrm{~min}$. Ten aphids were transferred to each of nine healthy I. batatas. The aphids were then killed by insecticide after $24 \mathrm{~h}$, and the plants were grown in the growth chamber for 2 months. 10-O infection was examined by RT-PCR-RFLP (see above). As a control, SPFMV-S was compared by the same method.

\section{RESULTS}

Isolation of a mild isolate of SPFMV. Four of the 249 SPFMV-infected I. batatas plants produced storage roots with mild symptoms. Plant 95-10 was chosen as the source of virus for further experiments because its daughter storage roots did not show any russet crack symptoms and showed only slight skin discoloration. Amplification using the NIb and CP primers described above yielded 1,463- and 1,337-bp fragments in addition to the expected 1,343-bp fragment. Digestion of these three amplicons together by EcoRI yielded two fragments of 715 and $628 \mathrm{bp}$ in addition to the undigested 1,463, 1,343, and 1,337 amplicons. Digestion by BamHI yielded four fragments of 1,044, 717, 620, and $419 \mathrm{bp}$ in addition to the 1,343-bp undigested amplicon. These results suggested that the plant was infected by multiple genetically distinct isolates of SPFMV and that further selection for a mild SPFMV isolate was required.

Although mechanical inoculation of the two Chenopodium spp. did result in local lesion formation, mechanical inoculation from Chenopodium spp. back to healthy $I$. nil for increase and maintenance of the isolates was unsuccessful. As an alternative, mild SPFMV isolates were separated using a dilution based method. Sap from symptomatic leaves of $I$. nil scions were triturated in 1,000 volumes of $0.1 \mathrm{M}$ potassium phosphate buffer $(\mathrm{pH}$ 7.0) and used 
for mechanical inoculation of healthy I. nil cotyledons. After 6 serial passages in I. nil, the isolates were examined by RT-PCR coupled with RFLP (RT-PCR-RFLP) analysis and compared to each other and the viruses in the original daughter roots.

Three distinct isolates were identified by RFLP analysis in different plants following serial passage. Following BamHI digestion, one isolate yielded a fragment of approximately $1,300 \mathrm{bp}$, another generated two fragments of approximately 1,000 and $400 \mathrm{bp}$, and the third generated two fragments of approximately 700 and $600 \mathrm{bp}$. EcoRI digestion only separated two isolates, one that yielded a fragment of approximately $1,300 \mathrm{bp}$, another generated a fragment of approximately $1,400 \mathrm{bp}$. The isolate that yielded the 1,300-bp fragment after digestion with both enzymes induced milder symptoms on upper leaves of $I$. nil than the other two isolates and was selected for further use and designated as SPFMV 10-O.

Host range and pathogenicity. Although $10-\mathrm{O}$ was not mechanically transmissible to $I$. batatas, it was transmitted by grafting with 10-O-infected $I$. nil seedlings. No symptoms were observed on the leaves of 10-O-infected I. batatas, in contrast to symptoms of chlorotic spots with purple rings observed on the leaves of SPFMV-S-infected plants (25). 10-Oinoculated $I$. batatas grew similarly to virus-free plants, and storage roots were asymptomatic, or in the sweetpotato cultivars Tosabeni and Koukei-14 there was a slight mild storage root skin discoloration (Fig. 1). Russet crack did not appear on any of the tested cultivars. This was in contrast to the russet crack, skin discoloration, and deformity observed in SPFMV-S infected storage roots (Fig. 1).
The yield of fresh storage roots of the 10-O-infected I. batatas was not significantly different from that of storage roots from noninfected I. batatas (Table 1). The weight of storage roots from plants infected with 10-O ranged from 137.5 to $237.4 \mathrm{~g}$, and the number of roots per stock ranged from 2.7 to 3.9 . These values were not significantly different from those obtained from the noninoculated controls (Student's $t$ test, $P>0.05$, Table 1).

I. nil and I. setosa were systemically infected by SPFMV-10-O infection, and the infection caused mottling and vein-clearing of the upper leaves, respectively. 10-O causes chlorotic spots on a few inoculated leaves of $C$. amaranticolor and C. quinoa. The other tested plants did not develop symptoms and were not infected by $10-\mathrm{O}$, as indicated by negative RT-PCR assays.

Sequence divergence and discrimination between SPFMV-10-O and SPFMV-S. The sequence of the $17813^{\prime} \mathrm{nt}$ bp fragment containing the NIb gene, the $\mathrm{CP}$ gene, and the $3^{\prime}$ untranslated region from the 10-O isolate was determined (DDBJ/EMBL/GenBank accession number $\mathrm{AB} 438224)$, and the $\mathrm{CP}$ gene sequence (nucleotide positions 613 to 1557 encoding 315 amino acids) was compared with the corresponding region of SPFMV-S (DDBJ/ EMBL/GenBank accession number D86371) and SPFMV-O (DDBJ/EMBL/GenBank accession number D16664). The 10-O sequence was 91.1 and $99.3 \%$ identical to SPFMV-S and SPFMV-O, respectively, at the nucleotide level, and 95.6 and $99.4 \%$, respectively, at the amino acid level. Based on these data, we designed an RFLP analysis that would distinguish between the 10$\mathrm{O}$ and SPFMV-S isolates.

Digestion of the 10-O amplicon yielded 3 fragments, 238, 214, and 36 bp in size, whereas the amplicon from SPFMV-S contained only one AluI site, which generated two fragments, 452 and $36 \mathrm{bp}$ in size, respectively (Fig. 2).

Cross-protection tests of 10-O. Plants inoculated with $10-\mathrm{O}$ and then challenged with SPFMV-S produced storage roots that either were asymptomatic or had only mild skin discoloration (Fig. 1). The disease severity ratings of these plants were slightly higher than those of plants inoculated with $10-\mathrm{O}$ only, but were significantly lower than those of plants inoculated with SPFMV-S only (Table 2). RFLP analysis did not detect SPFMV-S in storage roots of plants infected with $10-\mathrm{O}$ and then challenged with SPFMV-S. RFLP analysis readily detected SPFMV-S and 10-O in mixtures of sap from leaves of 10 plants infected with each virus. However, in leaves of 10 plants infected with 10-O and then challenged with SPFMV-S, RFLP analysis did not detect SPFMV-S at all.

Transmission of 10-O by aphids. 10-O was transmitted by aphids, but the rate of transmission was less ( 2 of 9 I. batatas cuttings tested) than for SPFMV-S (5 of 9 cuttings tested). However, further testing is required to determine if these differences are significant.

\section{DISCUSSION}

In this study, we found a mild isolate of SPFMV (10-O), which protects I. batatas from SPFMV-S infection. RT-PCR-RFLP revealed that SPFMV-S did not latently infect any 10-O-infected I. batatas. In contrast, when I. batatas was preinfected by inoculation with SPFMV-O $(15,26)$ and subsequently challenged with SPFMV-S, the two viruses coinfected, resulting in russet crack symptom expression and severe skin discoloration (data not shown).

Table 1. Disease severities and yield of storage roots of Ipomoea batatas

\begin{tabular}{|c|c|c|c|c|c|c|c|c|}
\hline \multirow[b]{2}{*}{ Experiment $^{\mathrm{a}}$} & \multirow[b]{2}{*}{ Year } & \multicolumn{2}{|c|}{ Day } & \multirow[b]{2}{*}{ Inoculum } & \multirow{2}{*}{$\begin{array}{l}\text { Average weight of } \\
\text { a storage root }(\mathrm{g})^{\mathbf{b}}\end{array}$} & \multirow{2}{*}{$\begin{array}{c}\text { Number of roots } \\
\text { in a stock }\end{array}$} & \multicolumn{2}{|c|}{ Average yield of a stock } \\
\hline & & Planting & Harvest & & & & Weight $(g)^{b}$ & $\%$ to noninoculated \\
\hline \multirow[t]{2}{*}{$\mathrm{A}$} & 2000 & 8 Jun & $26 \mathrm{Oct}$ & $10-\mathrm{O}$ & 208.9 & 2.7 & 564.0 & 96 \\
\hline & & & & $-^{\mathrm{c}}$ & 218.1 & 2.7 & 589.0 & - \\
\hline \multirow[t]{2}{*}{ B } & 2000 & $9 \mathrm{Jun}$ & $7 \mathrm{Nov}$ & $10-\mathrm{O}$ & 215.0 & 3.6 & 774.0 & 97 \\
\hline & & & & - & 211.1 & 3.8 & 802.0 & - \\
\hline \multirow[t]{2}{*}{$\mathrm{C}$} & 2001 & 29 May & $30 \mathrm{Oct}$ & $10-\mathrm{O}$ & 183.4 & 3.5 & 639.0 & 98 \\
\hline & & & & - & 204.8 & 3.2 & 654.0 & - \\
\hline \multirow[t]{2}{*}{$\mathrm{D}$} & 2001 & 29 May & $19 \mathrm{Nov}$ & $10-\mathrm{O}$ & 210.2 & 3.9 & 819.0 & 104 \\
\hline & & & & - & 208.3 & 3.8 & 790.0 & - \\
\hline \multirow[t]{2}{*}{ E } & 2001 & 16 May & $26 \mathrm{Oct}$ & $10-\mathrm{O}$ & 252.3 & 2.8 & 698.0 & 95 \\
\hline & & & & - & 246.0 & 3.0 & 738.0 & - \\
\hline \multirow[t]{2}{*}{$\mathrm{F}$} & 2002 & 15 May & $5 \mathrm{Nov}$ & $10-\mathrm{O}$ & 237.4 & 2.7 & 641.0 & 100 \\
\hline & & & & - & 279.1 & 2.3 & 642.0 & - \\
\hline \multirow[t]{2}{*}{ G } & 2002 & 15 Мау & $11 \mathrm{Nov}$ & $10-\mathrm{O}$ & 180.0 & 3.6 & 648.0 & 105 \\
\hline & & & & - & 176.3 & 3.5 & 617.0 & - \\
\hline \multirow[t]{2}{*}{$\mathrm{H}$} & 2003 & 13 May & $13 \mathrm{Nov}$ & $10-\mathrm{O}$ & 225.9 & 3.3 & 745.5 & 99 \\
\hline & & & & - & 243.3 & 3.1 & 754.2 & - \\
\hline \multirow[t]{2}{*}{ I } & 2003 & 15 May & 29 Oct & $10-\mathrm{O}$ & 137.5 & 3.9 & 536.3 & 92 \\
\hline & & & & - & 176.5 & 3.3 & 582.5 & - \\
\hline \multirow[t]{2}{*}{$\mathrm{J}$} & 2003 & 15 May & $13 \mathrm{Nov}$ & $10-\mathrm{O}$ & 180.0 & 2.9 & 522.0 & 95 \\
\hline & & & & - & 183.9 & 3.0 & 551.7 & - \\
\hline
\end{tabular}

\footnotetext{
${ }^{\text {a }}$ For each treatment, 30 cuttings of the I. batatas cv. Tosabeni were used.

b Not significant at the $5 \%$ level by Student's $t$ test.

c - , Not inoculated.
} 
Occasionally, mild viruses may affect the phenotypic expression and nutrient uptake in infected plants. Gentiana scabra inoculated with a mild isolate of Bean yellow mosaic virus showed an increase in the number of flowers (23). Similarly, $G$. scabra produced more flowers after infection with a mild isolate of Cucumber mosaic virus (20). Sayama et al. reported that ascorbic acid accumulates in the fruits of tomato infected with a mild isolate of $\mathrm{Cu}$ cumber mosaic virus (21). The yield of fresh storage roots produced by 10-Oinfected cuttings was almost equal to that of healthy plants. 10-O appeared to have little effect on the storage roots of I. batatas, as the average weight of a root and the number of roots per plant were not significantly different. Further study is needed to evaluate the effects of 10-O infection on the quality and nutrient composition of sweetpotato.

Transmission tests suggested that $10-\mathrm{O}$ could be transmitted between I. batatas by aphids in the fields. Some mild isolates of other viruses appeared to have poor aphid transmissibility $(10,11,22)$. Lack of transmissibility is a desirable trait in mild viruses, as it minimizes the risk of natural spread. However, spreading of $10-\mathrm{O}$ in fields might be limited because of its narrow host range. Even if 10-O infects other plants, our data suggest that the damage would not be serious due to the low pathogenicity of the virus.

Based on the nucleotide sequence of its $3^{\prime}$ noncoding region and $\mathrm{CP}$ gene, $10-\mathrm{O}$ is genetically more similar to SPFMV-O than to SPFMV-S. As the amino acid sequence identity of the $\mathrm{CP}$ of $10-\mathrm{O}$ with the $\mathrm{CP}$ of SPFMV-O was $99.4 \%, 10-O$ could be classified as an isolate of SPFMV-O. However, the nucleotide sequence of the $5^{\prime}$ terminal region of $10-\mathrm{O}$ was more similar to
SPFMV-S than to SPFMV-O (S. Yamasaki et al., unpublished). We are currently determining the complete nucleotide sequence of $10-\mathrm{O}$ and attempting to develop infectious clones. In further studies, genetic recombinants among these isolates could reveal which gene or region is responsible for the mild symptom phenotype and the cross-protection ability.

I. batatas was rarely infected with $10-\mathrm{O}$ by sap inoculation. From a practical point of view, large numbers of the infected cuttings should be prepared at one time to use for commercial production. We graft- inoculated $I$. nil with $10-\mathrm{O}$ to prepare 10 O-infected cuttings. We confirmed that 10$\mathrm{O}$ could be maintained in I. batatas in subsequent generations once it was inoculated, and that the mild characteristic of the infection was stable in the infected roots. Therefore, if farmers are provided with the 10-O-infected roots or cuttings, they would be able to maintain, propagate, and cultivate the 10-O-infected roots or cuttings by themselves.

In Japan, cosmetic appearance of vegetables and fruits including sweetpotato is very important for marketing, because consumers

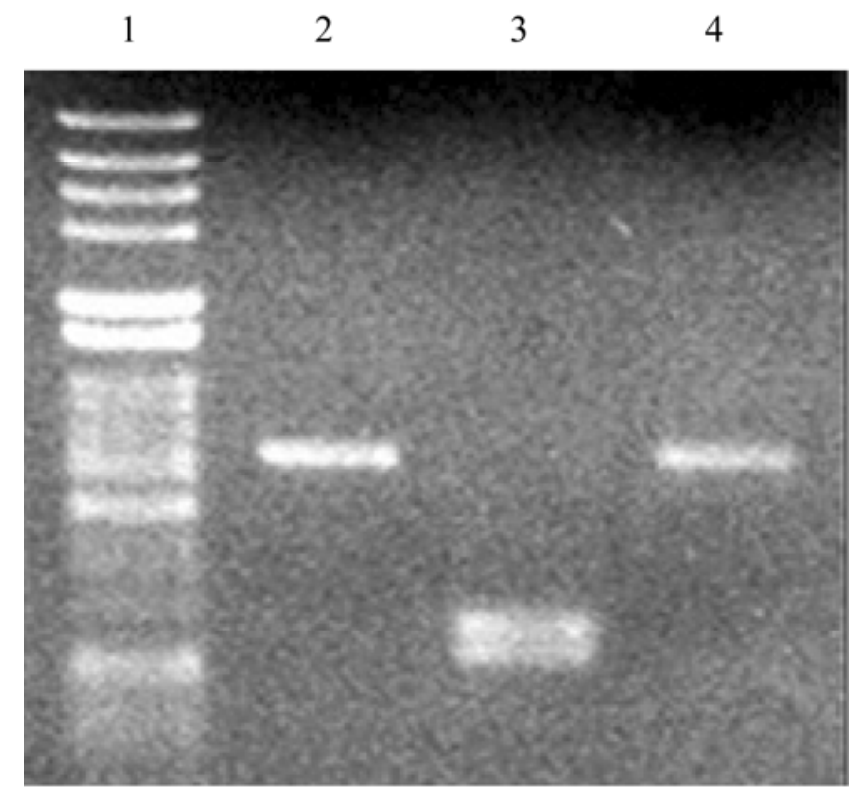

Fig. 2. Differentiation of the mild isolate 10-O and Sweet potato feathery mottle virus, severe strain (SPFMV-S) by reverse transcription-polymerase chain reaction (RT-PCR) followed by AluI digestion. Products of PCR were generated using primers 490-RT, 490-5', and 490-3'. Amplified products were digested with AluI. Total RNA extracted from Ipomoea batatas that had been infected with 10-O (lane 2), SPFMV-S (lane 3), and inoculated with 10-O and then challenged with SPFMV-S (lane 4).

A

B

$\mathrm{C}$

$\mathrm{D}$

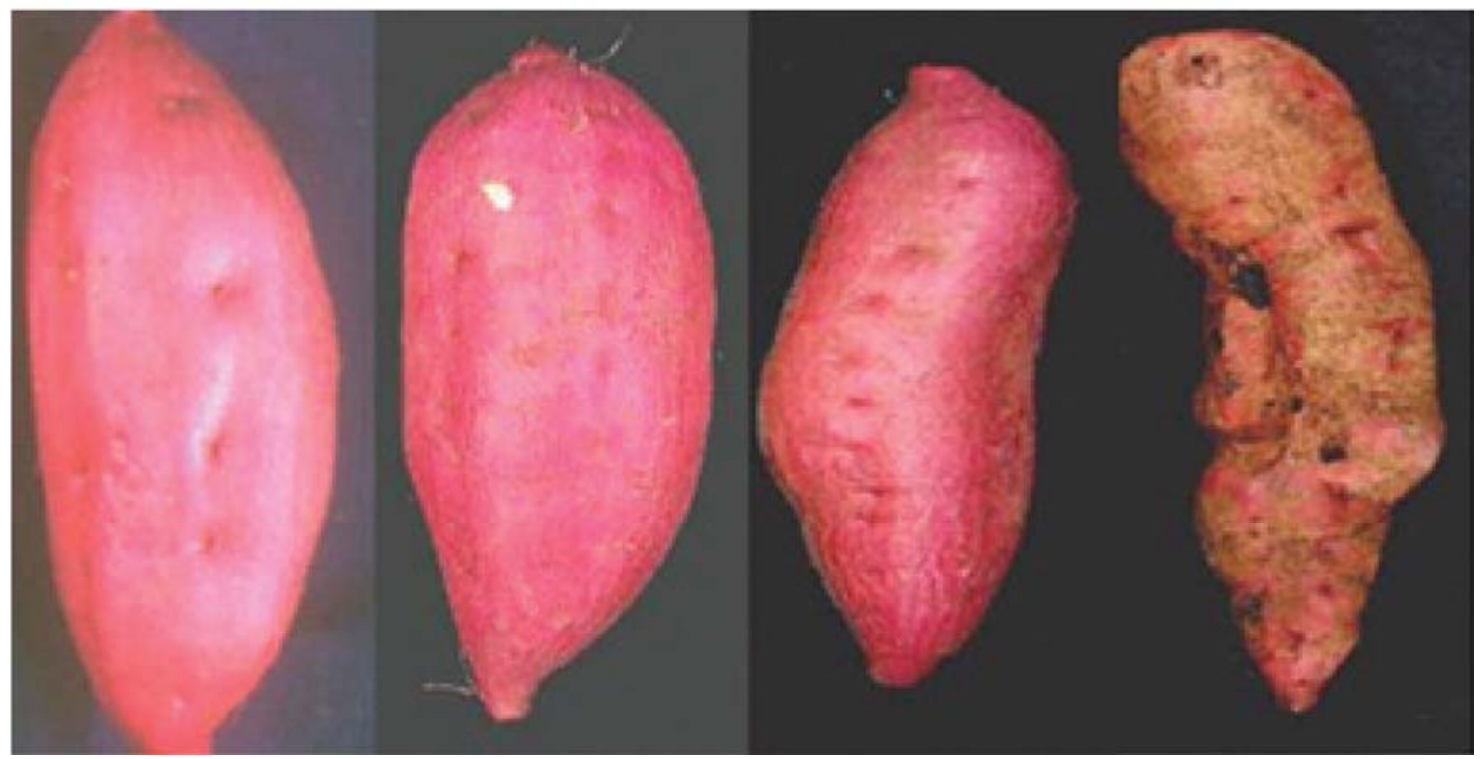

Fig. 1. Storage roots of Ipomoea batatas (cv. Tosabeni): A, healthy; B, infected with mild isolate 10-O; C, 10-O infected and challenge-inoculated with Sweet potato feathery mottle virus, severe strain (SPFMV-S); and D, SPFMV-S infected. 
Table 2. Cross-protection of mild isolate 10-O against the severe strain of Sweet potato feathery mottle virus (SPFMV-S) infection in the field

\begin{tabular}{|c|c|c|c|c|c|c|c|c|c|c|c|c|}
\hline \multirow[b]{2}{*}{ Experiment } & \multirow[b]{2}{*}{ Year } & \multicolumn{2}{|c|}{ Day } & \multirow{2}{*}{$\begin{array}{l}\text { Preliminary } \\
\text { inoculation }\end{array}$} & \multirow{2}{*}{$\begin{array}{l}\text { Challenge } \\
\text { inoculation }\end{array}$} & \multirow{2}{*}{$\begin{array}{l}\text { Roots } \\
\text { tested }\end{array}$} & \multirow{2}{*}{$\begin{array}{c}\text { Disease } \\
\text { incidence }\end{array}$} & \multicolumn{4}{|c|}{ No. of plants with symptoms ${ }^{a}$} & \multirow{2}{*}{$\begin{array}{r}\text { Disease } \\
\text { severity }\end{array}$} \\
\hline & & Planting & Harvest & & & & & $\mathbf{0}$ & 1 & 2 & 3 & \\
\hline \multirow[t]{3}{*}{ A } & 2000 & 8 Jun & 26 Oct & $10-\mathrm{O}$ & SPFMV-S & 30 & 16.7 & 25 & 5 & 0 & 0 & 5.6 \\
\hline & & & & $-^{c}$ & SPFMV-S & 30 & 100 & 0 & 0 & 0 & 30 & 100 \\
\hline & & & & $10-\mathrm{O}$ & - & 30 & 20.0 & 24 & 6 & 0 & 0 & 6.7 \\
\hline \multirow[t]{3}{*}{ B } & 2000 & $9 \mathrm{Jun}$ & 7 Nov & $10-\mathrm{O}$ & SPFMV-S & 30 & 40.0 & 18 & 10 & 2 & 0 & 15.6 \\
\hline & & & & - & SPFMV-S & 30 & 100 & 0 & 0 & 6 & 24 & 93.3 \\
\hline & & & & $10-\mathrm{O}$ & - & 30 & 50.0 & 15 & 13 & 2 & 0 & 18.9 \\
\hline \multirow[t]{3}{*}{$\mathrm{C}$} & 2001 & 15 May & 15 Oct & $10-\mathrm{O}$ & SPFMV-S & 30 & 23.3 & 23 & 5 & 0 & 2 & 12.2 \\
\hline & & & & - & SPFMV-S & 30 & 100 & 0 & 0 & 7 & 23 & 92.2 \\
\hline & & & & $10-\mathrm{O}$ & - & 28 & 21.4 & 22 & 6 & 0 & 0 & 7.1 \\
\hline \multirow[t]{3}{*}{$\mathrm{D}$} & 2001 & 29 May & $30 \mathrm{Oct}$ & $10-\mathrm{O}$ & SPFMV-S & 30 & 16.7 & 25 & 3 & 2 & 0 & 7.8 \\
\hline & & & & - & SPFMV-S & 30 & 100 & 0 & 3 & 4 & 23 & 88.9 \\
\hline & & & & $10-\mathrm{O}$ & - & 30 & 6.7 & 28 & 2 & 0 & 0 & 2.2 \\
\hline \multirow[t]{3}{*}{ E } & 2001 & 29 May & $19 \mathrm{Nov}$ & $10-\mathrm{O}$ & SPFMV-S & 30 & 30.0 & 21 & 8 & 1 & 0 & 11.1 \\
\hline & & & & - & SPFMV-S & 30 & 100 & 0 & 3 & 8 & 19 & 84.4 \\
\hline & & & & $10-\mathrm{O}$ & - & 30 & 20.0 & 24 & 5 & 1 & 0 & 7.8 \\
\hline \multirow[t]{3}{*}{$\mathrm{F}$} & 2001 & 16 May & 26 Oct & $10-\mathrm{O}$ & SPFMV-S & 30 & 30.0 & 21 & 7 & 2 & 0 & 12.2 \\
\hline & & & & - & SPFMV-S & 30 & 100 & 0 & 1 & 7 & 22 & 90.0 \\
\hline & & & & $10-\mathrm{O}$ & - & 30 & 10.0 & 27 & 3 & 0 & 0 & 3.3 \\
\hline \multirow[t]{3}{*}{ G } & 2002 & 15 May & $5 \mathrm{Nov}$ & $10-\mathrm{O}$ & SPFMV-S & 79 & 22.8 & 61 & 15 & 3 & 0 & 8.9 \\
\hline & & & & - & SPFMV-S & 80 & 93.8 & 5 & 8 & 16 & 51 & 80.4 \\
\hline & & & & $10-\mathrm{O}$ & - & 40 & 15.0 & 34 & 6 & 0 & 0 & 5.0 \\
\hline \multirow[t]{3}{*}{$\mathrm{H}$} & 2003 & 13 May & $13 \mathrm{Nov}$ & $10-\mathrm{O}$ & SPFMV-S & 49 & 12.2 & 43 & 4 & 2 & 0 & 5.4 \\
\hline & & & & - & SPFMV-S & 34 & 97.1 & 1 & 2 & 0 & 31 & 93.1 \\
\hline & & & & $10-\mathrm{O}$ & - & 41 & 9.8 & 37 & 4 & 0 & 0 & 3.3 \\
\hline
\end{tabular}

${ }^{\text {a }}$ Symptoms were categorized by disease indices as follows: 0 , no symptoms; 1 , slight skin discoloration; 2, mild skin discoloration; 3 , russet crack disease or severe skin discoloration. All roots were scored 5 months after putting inoculated cuttings into soil.

${ }^{\mathrm{b}}$ Disease severity $=\Sigma($ disease index $\times$ number of plants $) /(3 \times$ total number of roots $) \times 100$.

c-, Not inoculated.

consider that good appearance is an indication of good quality and taste. Russet crack or skin discoloration in sweetpotato drastically decreases their commercial value. Although sweetpotatoes with russet crack symptoms have very low commercial value, 10-O-infected storage roots were almost equal to virus-free roots in apparent marketability. We anticipate that the ability of 10-O to protect against russet crack, especially over several generations of crop production, will save considerable commercial value of sweetpotato in Japan.

\section{ACKNOWLEDGMENTS}

We are very grateful to Christopher A. Clark, Louisiana State University, for his helpful suggestions and valuable advice to improve our manuscript.

\section{LITERATURE CITED}

1. Abad, J. A., Conkling, M. A., and Moyer, J. W. 1992. Comparison of the capsid protein cistron from serologically distinct strains of Sweet potato feathery mottle virus (SPFMV). Arch. Virol. 126:147-157.

2. Cali, B. B., and Moyer, J. W. 1981. Purification, serology, and particle morphology of two russet crack strains of Sweet potato feathery mottle virus. Phytopathology 71:302-305.

3. Campbell, R. N., Scheuerman, R. W., and Hall, D. H. 1997. Russet crack disease of sweet potatoes. Calif. Agric. (Aug.):8-10.

4. Costa, A. S., and Müller, G. W. 1980. Tristeza control by cross protection: A U.S.-Brazil cooperative success. Plant Dis. 64:538-539.

5. Fuji, S., Iida, T., and Nakamae, H. 2000. Selection of an attenuated strain of Japanese yam mosaic virus and its use for protecting yam plants against severe strains (in Japanese with English summary). Jpn. J. Phytopathol. 66:35-39.

6. Fulton, R. W. 1986. Practices and precautions in the use of cross protection for plant virus disease control. Annu. Rev. Phytopathol. 24:67-81.

7. Gonsalves, D. 1998. Control of Papaya ring spot virus in papaya: A case study. Annu. Rev.
Phytopathol. 36:415-437.

8. Hanada, K., Sakai, J., and Onuki, M. 1997. Detection of sweet potato feathery mottle virus by RT-PCR using primers derived from conserved sequence among strains. Ann. Phytopathol. Soc. Jpn. 63:259.

9. Kosaka, Y., and Fukunishi, T. 1997. Multiple inoculation with three attenuated viruses for the control of cucumber virus disease. Plant Dis. 81:733-738.

10. Kosaka, T., Ryang, B.-S., Kobori, T., Shiomi, H., Yasuhara, H., and Kataoka, M. 2006. Effectiveness of an attenuated Zucchini yellow mosaic virus isolate for cross-protecting cucumber. Plant Dis. 90:67-72.

11. Lecoq, H., Lemaire, M., and Wipfscheibel, C. 1991. Control of Zucchini yellow mosaic virus in squash by cross protection. Plant Dis. 75:208-211.

12. McKinney, H. H. 1929. Mosaic diseases in the Canary Islands, West Africa, and Gibraltar. J. Agric. Res. 39:557-578.

13. Mitoma, K., Kumazawa, M., Hirayama, S., Abe, S., Yoshino, M., and Kitauchi, Y. 1991. Control of the Obijo-Sohi disease in sweetpotato. Bull. Oita Pref. Agric. Res. Cen. 21:85116 (in Japanese).

14. Mori, M., Sakai, J., Kimura, T., Usugi, T., Hayashi, T., Hanada, K., and Nishiguchi, M. 1995. Nucleotide sequence analysis of two nuclear inclusion body and coat protein genes of a Sweet potato feathery mottle virus severe strain (SPFMV-S) genomic RNA. Arch. Virol. 140:1473-1482.

15. Mori, M., Usugi, T., Hayashi, T., and Nishiguchi, M. 1994. Nucleotide sequence at the $3^{\prime}-$ terminal region of Sweet potato feathery mottle virus (ordinary strain, SPFMV-O) RNA. Biosci. Biotech. Biochem. 58:965-967.

16. Onuki, M., Sakai, J., Mori, M., Usugi, T., Tsuda, S., and Hanada, K. 1994. Detection of Sweet potato feathery mottle virus from infected sweetpotato plants by RT-PCR. Ann. Phytopathol. Soc. Jpn. 60:739-740 (Abstr. in Japanese)

17. Oshima, N., Komochi, S., and Goto, T. 1965. Control of virus disease using an attenuated strain (1) Control of mosaic in tomato. Bull. Hokkaido Agric. Exp. Stn. Jpn. 85:23-33 (in Japanese).
18. Sakai, J., Kai, Y., and Hanada, K. 2000. Occurrence of SPFMV strains in sweetpotato conservation field in KNAES. Ann. Phytopathol. Soc. Jpn. 66:258 (Abstr. in Japanese).

19. Sakai, J., Mori, M., Morishita, T., Tanaka, M., Hanada, K., Usugi, T., and Nishiguchi, M. 1997. Complete nucleotide sequence and genome organization of Sweet potato feathery mottle virus ( $\mathrm{S}$ strain) genomic RNA: The large coding region of the P1 gene. Arch. Virol. 142:1553-1562.

20. Sayama, H., Kominato, M., Atarashi, H Takayanagi, N., Yamada, M., Hikage, T., and Yoshiike, T. 2006. Control of Cucumber mosaic virus (CMV) in Gentian by Satellite RNA containing attenuated CMV strains. Acta Hortic. 722:147-153

21. Sayama, H., Sato, T., and Kominato, M. 1994. Biochemical and morphological effects of an attenuated Cucumber mosaic virus, CMVNDM-1 on tomato plants. 24th Int. Hortic. Congr. (Abstr.) O-57-1.

22. Sayama, H., Sato, T., Kominato, M., Natsuaki, T., and Kaper, J. M. 1993. Field testing of a satellite-containing attenuated strain of $\mathrm{cu}$ cumber mosaic virus for tomato protection in Japan. Phytopathology. 83:405-410.

23. Uga, H., Kobayashi, O. Y., Hagiwara, K., Honda, Y., and Omura, T. 2004. Selection of an attenuated isolate of Bean yellow mosaic virus for protection of dwarf gentian plants from viral infection in the field. Ann. Phytopathol. Soc. Jpn. 70:54-60.

24. Usugi, T., and Maoka, T. 1993. Properties of Sweet potato feathery mottle virus Tokushima strain (SPFMV-T) Ann. Phytopathol. Soc. Jpn. 59:331-332 (Abstr. in Japanese).

25. Usugi, T., Nakano, M., Onuki, M., Maoka, T., and Hayashi, T. 1994. A new strain of Sweet potato feathery mottle virus that causes russet crack on fleshy roots of some Japanese cultivars of sweetpotato. Ann. Phytopathol. Soc. Jpn. 60:545-554.

26. Usugi, T., Nakano, M., Shinkai, A., and Hayashi, T. 1991. Three filamentous viruses isolated from sweetpotato in Japan. Ann. Phytopathol. Soc. Jpn. 57:512-521. 